\title{
Image Processing Application for Lipa Saqbe Mandar
}

Research Article

\author{
Gustia Ochtavia ${ }^{1 *}$, Muhammad Sarjan (D)², Akhmad Qashlim (iD 3
}

1. Departement of Informatics, Universitas Al Asyariah Mandar, Polewali Mandar, Indonesia

2. Departement of accountancy, Universitas Al Asyariah Mandar, Polewali Mandar, Indonesia

3. Departement of Information System, Universitas Al Asyariah Mandar, Polewali Mandar, Indonesia

\author{
"gustiaochtavia98@gmail.com (coresponden author) \\ muhsarjan2018@gmail.com \\ qashlim@mail.unasman.ac.id
}

Article history :

Received : 28 Aug 2021

Accepted : 08 Nov 2021

Available online : 14 Feb 2022

\section{ABSTRACT}

Seeing from today's technological developments, it is growing rapidly, but there are still many people, especially the younger generation today, whose understanding is still very lacking, in recognizing any motifs or patterns in Lipa Saqbe Mandar. From these problems, an image processing application is needed to recognize the Lipa Saqbe pattern that can be used to help facilitate the community or the younger generation, where the camera application will be directed to Lipa Saqbe and will then provide information or identify the name of the Lipa Saqbe pattern or motif. This system uses the template matching method, which functions to match each part of an image with the image that becomes the template (reference). One of the applied methods of the convolation technique. This method is often used to identify character images of letters, numbers, fingerprints and other image matching applications. This application is built using the Java programming language, and database. With the image management process using the template matching method through a scanning process, so that it can identify the name of the motif or pattern in Lipa Saqbe.

Keywords: Android, image management, template machine, lipa saqbe.

Journal of Intelligent Computing and Health Informatics is licensed under a Creative Commons Attribution-Share Alike 4.0 International License (CC BY-SA 4.0). 


\section{INTRODUCTION}

Indonesia has a variety of ethnic groups scattered throughout the archipelago. Among the various ethnic groups in Indonesia, each has its own characteristics (M Dedy Rosyadi, 2017). One of the woven products with silk thread is a silk lipa from the Mandar Tribe who inhabits the Polewali Mandar (Polman) Regency in West Sulawesi Province. Mandar silk lipa is also known as Lipa Saqbe Mandar.

Lipa Saqbe Mandar has two characteristics in its pattern or motif, namely sure' and flowers. From the two motifs or patterns, other names are derived based on their philosophy from social, religious, and cultural aspects (Ihwan, 2018). There are 11 motifs of the Mandar silk lipa, namely sure' penghulu, sure' mara'dia, sure' puang limboro, sure' puang lembang, sure' batu dadzima, sure' padzadza, sure' salaka, sure' gattung screen, sure' penja, sure' bandera, and sure' beru-beru (Adyla, 2018).

However, the similarity of patterns or motifs is sometimes difficult to distinguish, on the other hand, human nature is limited in recognizing objects, resulting in frequent errors in identifying the type of pattern of batik or silk motifs. As a unique cultural heritage owned by various regions in Indonesia, as a traditional wealth, silk cloth is very important, it must be cared for and preserved by (Maulida et al., 2019). The form of conservation carried out by utilizing information technology is also a challenge for the sustainability of Indonesian culture. Technology should be an alternative strategy to develop the culture of today's digital era (Musthofa, 2020). Image processing is a collective term for various existing techniques to manipulate and modify images in different ways. Image processing applications that actually use the basics of image processing can be classified as follows increase brightness and contrast, noise cancellation, and object shape search.

Image filtering Digital image processing uses filters to remove high frequencies from an image. The purpose of filtering is to make the image better or sharper for analysis. Filtering is inseparable from the kernel (mask) and convolution theory. Edge detection is an image processing process that uses a filter implemented by convolution. The convolution operation works by shifting the kernel pixel by pixel and the result is stored in a new matrix.

Digital image processing obtains an analysis of strokes of batik image patterns in terms of shape, color, and texture. From the analyzed characteristics, a classification table is used to identify the types of batik motifs. In this study, batik classifiers were carried out using kNN classifiers based on the structure and color of batik motifs by extracting statistical characteristics from primary and secondary characteristics (Riesmala et al., 2012). Furthermore, the Daubechies level 2 wavelet transformation method was used to extract the mean, energy, and standard deviation texture characteristics as input for the lattice-graded batik sample (Rangkuti, 2014).
Furthermore, by extracting the texture properties of the batik pattern which is always invariant to rotation, using the Rotation Full Robust Local Binary Pattern Magnification (rotCRLBP M) method and maintaining the magnitude property, these properties are an artificial neural network classified as 1 using a probabilistic method (Kurniawardhani et al., 2014). Then use the vector quantization method on the Android platform to determine the texture of batik based on the frequency function of contour detection (Sulistyo, 2016).

In the search, an image can identify one type of batik pattern, but one image cannot identify more than one type of batik pattern. On the other hand, in some cases batik images have several batik designs. Based on this, we need a system that can identify several types of batik motifs in an image. Identification of shapes can be used as a solution, either on the same image or if there are several things that look similar, because each shape in a batik pattern is unique from one another (Fuad \& Suciati, 2018).

With pattern recognition, you can find out the pattern of the fabric. Patterns are an important feature for surface analysis of many types of images. Currently, there are many image processing methods such as pattern matching.

On this basis, a research article was made on the application of image processing with the Template Matchin method to find out the fabric motifs in Lipa saqbe. Hopefully this will help with the image recognition process and allow you to use your phone's camera to recognize fabric patterns through images on your mobile device. And furthermore, this application will help the community, especially the younger generation to provide information about Lipa saqbe motifs and can participate in preserving the cultural heritage of Lipa saqbe mandar silk fabrics.

\section{LITERATURE REVIEW}

Lipa Saqbe Mandar (or commonly called Lipa saqbe) is a unique culture of the Mandar tribe, still preserved today, because the Mandar people wear Lipa Saqbe at every event held both in traditional Mandar cultural ceremonies such as weddings and moments of mourning (Adyla et al., 2018). In terms of samples, Lipa Saqbe Mandar comes in two models, Sure 'and Bunga. Sure' is certainly the original pattern without any floral decorations on the pattern. While the flowers are decorated according to the flowers in the pattern (Ihwan, 2018). See examples of Mandar silk fabrics below. Types of patterns sureq lipa mandar includes are sureq pangulu, sureq sembilan-sembilan, sureq tabu-tabu, and sureq tepi bunga.

Sureq pangulu pattern is a style / sureq that is quite old and classic even some Mandar people call it the oldest pattern. Sureq Pangulu was built at least 15 lines that intersect each other to form boxes measuring $3 \times 3 \mathrm{~cm}$. In the box there are still 9 smaller squares inside with fine 
lines that coincide more tightly. The basic colors of this weave are dark saqbe, or black, and purple. The stripe motifs are white or light saqbe, reddish-black, and purple. The stripe motifs are white or light reddish saqbe. This type of sureq is only used by the high nobility in Mandar, or among the traditional rulers, male royals, such as those with the title Maraqdia, Tommuane, Se 'I Puang Tomuane. During a party or meeting of traditional councils, this lipa is widely used by nobles who take part in the event. Lipa sureq pangulu pattern can beshown in Fig. 1.

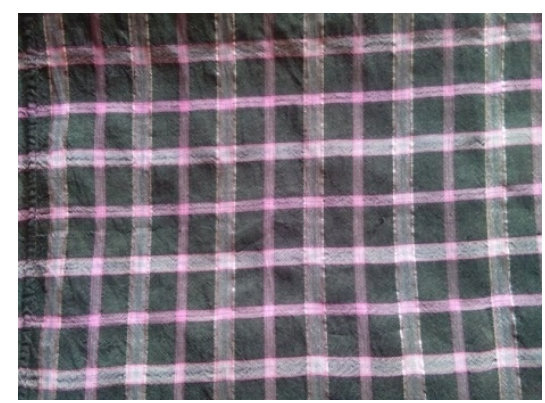

Fig 1. Sureq pangulu pattern.

The sureq pattern sembilan-sembilan have a basic colors motif that consist of nine colors, $60 \mathrm{~cm}$ wide and $100 \mathrm{~cm}$ high, dark blue, yellow, pink, light blue, brown, beige, orange, white and red. The size of the boxes is $2 \mathrm{x}$ $2 \mathrm{~cm}$. It is called Sureq sembilan-sembilan because this woven is decorated with silver thread, who wear this lipa sembilan-sembilan, namely the people who are in charge of delivering wedding invitations. The bright color of this lipa sembilan-sembilan is also worn by many mandar female dancers. Lipa sureq sembilan-sembilan pattern can be shown in Fig. 2.

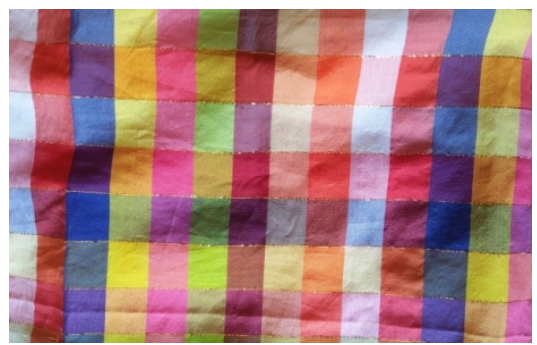

Fig 2. Sureq sembilan-sembilan pattern.

Sureq tabu-tabu made by Indian thread with basic colors of brown and orange, a combination of light brown, silver (algae) with Plant Motifs (Flower sui-sui) with an area of $60 \times 100 \mathrm{~cm}$. This type of sureq is worn by people who hold traditional ceremonies, weddings, and dancers. Lipa sureq tabu-tabu pattern can be shown in Fig. 3.

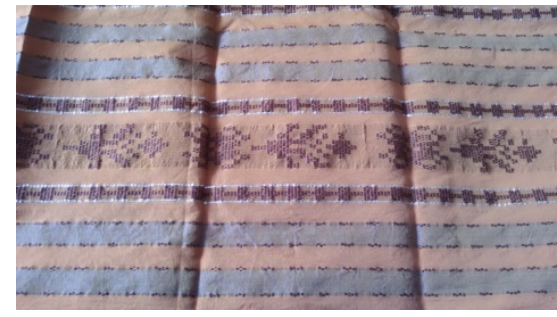

Fig 3. Sureq tabu-tabu pattern.

Sureq bunga pinggir also made by Indian thread with a blue base color, a combination of white and combined with yellow silver thread with a white and yellow ciru flower motif with an area of $60 \times 100 \mathrm{~cm}$. This type of sureq is worn by people who hold traditional ceremonies, weddings, and dancers. Lipa sureq bunga pinggir pattern can be shown in Fig. 4.

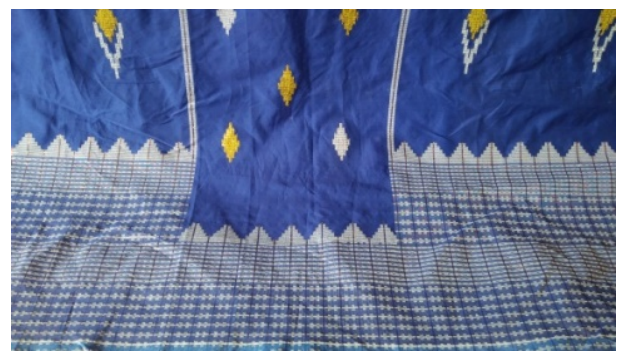

Fig 4. Sureq bunga pinggir pattern.

\subsection{Defenition}

Definition of Image in Webster's dictionary, the definition of image is "representation, appearance or imitation of one or more objects". Images can be grouped into visible and hidden images. Visible images for example, photos, images that appear on the monitor screen (optical image). Hidden images, such as image data in files (digital images). To make it visible to the human eye, you need to turn the image display into a visual interface instead of a display. for example, display an image on your screen. Because the data is in digital format, digital images can be processed by a computer. (Amalia, 2018).

\subsection{Image processing}

Image Processing is an umbrella term for different techniques for manipulating and modifying images in different ways. The real image processing applications using the basic principles of image processing can be classified as follows (Kadir \& Susanto, 2013) that includes are increase brightness and contrast, noise cancellation, and search object shape. Digital image processing stages as follow in Fig. 5.

The following steps are important in digital image processing as follow two stages are image processing and pattern recognition. Detail stagses can be shown in Fig. 5.

- Collecting digital images. Getting an image is the first step to getting a digital image. The purpose of image acquisition is to determine what data is needed and what data should be processed afterwards. This step 


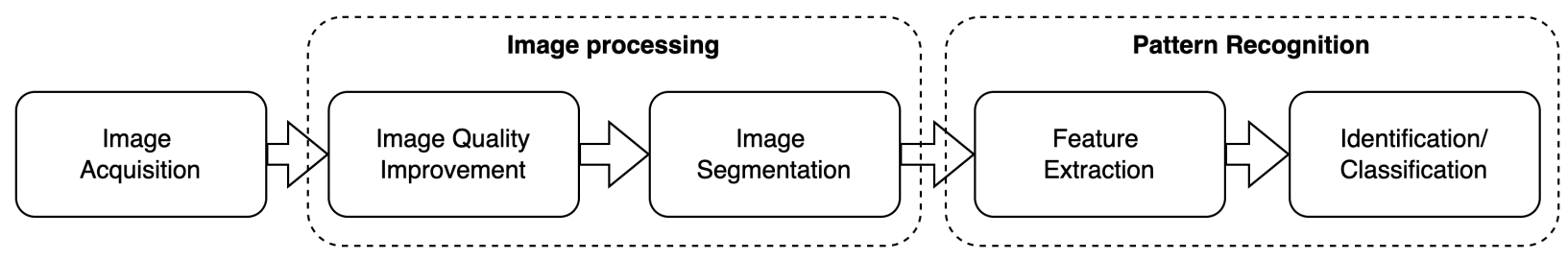

Fig 5. Digital image processing stage.

begins by capturing the subject and taking it over by various scanners, which are then converted into an image. Imaging is the act of converting visible images (photos, paintings, paintings, landscapes, etc.) into digital form. Photos, some of them. The devices includes are camera traditional, digital camera, conventional camera and analog converter to digital, scan, and IR-ray photo.

- Process. This stage is a stage where the image method will be selected before processing, the important things in this stage are:

(1) Image quality improvement (contrast, brightness, etc.) for resulting image is better than the original image;

(2) Eliminate noise. In this case, problematic noise is filtered out or removed to avoid damage to the image;

(3) Image restoration (image restoration). This is a stage in processing a bad image back to the way it was before;

(4) Transformation (Image Transformation). Where the transformation is a change in the structure or shape of the image;

(5) Determine the part of the image to be observed.

- Image segmentation. Image segmentation is the process of taking objects in one image or dividing the image into several regions. Each object or area has similar properties. For images with many objects, the process of classifying all objects is certainly more complicated. As a rule, segmentation is carried out to obtain objects of interest (Kadir \& Susanto, 2013).

- Representation and description. In this case, feature extraction and selection is performed when the region is represented by an equation and the feature class can be distinguished from the image.

- Introduction and Interpretation. The introduction step aims to label an object with the information provided by the descriptor, and the interpretation step aims to give meaning to a group of known objects.

- Knowladge base. The knowledge base helps guide various operations and serves as a reference for pattern matching or pattern recognition.

\subsection{Template matching}

Template Maching is a digital image processing technique that works to match parts of a pattern (reference). The input image containing the specified pattern is compared to the reference pattern. The sample focuses on the part of the image to compare and shows the optimal number of points for the pattern. Repeat this step to compare all input images. Repeat this step to compare all input images (Bahri \& Maliki, 2012). One method of applying the convolution method is the sample comparison method. Convolution is done by combining the input image with the reference source image (Bowo \& Hidayatno, 2011).

\subsection{Tools}

- PHP (Hypertext PreProcessor) is a script that is integrated with html and is on the server (server side HTML embedded scripting) which is used to create dynamic web pages so that this mechanism causes the information received to be always new (Haerulah \& Ismiyatih, 2017).

- MySQL (My Structure Query Language) it is a database management system software SQL (Database Management System) or DBMS that will function as a data storage medium for later display on the website.

- XAMPP Is a software that functions to run PHP-based websites and uses MySQL data processing on a local computer. XAMPP functions as a server on a computer or a virtual server panel that can assist in previewing so that you can modify websites without having to be online or connected to the internet later.

\section{RESEARCH METHODS}

The material used in this study is data on lipa saqbe patterns which consist of two patterns, namely sureq and flowers. From this data then make business rules to be embedded in the software. This study also uses literature studies in the form of articles, textbooks, and references that can support research. This research is planned to make an application design that can identify the pattern of lipa saqbe with template maching method. For this reason, the following research steps were carried out:

- Documenting the types of lipa saqbe patterns, both sureq and floral patterns.

- From the documentation, obtained data regarding procedures, rules, and related components that will be modeled in the design of the planned application.

- System analysis is modeled into one form of system design.

- Analyzing cultural problems in a society in preserving the understanding of mandar culture in this case is the mandar lipa or lipa saqbe.

- From the problems that arise in the preservation, it is necessary to have a system that stores the data and can be accessed when needed.

- In the process of achieving a solution, it is hoped that conclusions will be obtained that will meet the research objectives and answer the hypothesis.. 
This research adopts the template matching method used to perform object detection in this final project is Template Matching. Template matching is a technique in digital image processing to find small parts of the image that match the image template. The light energy that radiates from a form hits the retina of the eye and is converted into neural energy which is then sent to the brain. Then there is a search among the existing templates. If a template is found to match (match) the pattern, then the subject can recognize the shape. After a match between the object and the template occurs, further processing and interpretation of the object can occur

\section{RESULTS AND DISCUSSION}

The results of research on image processing applications to determine the style of Lipa Saqbe using the Java programming language, the program that is built must be in accordance with the design that has been designed so that it can meet the needs of the user. In this case, the system design is translated into a standard programming language. The results of this study can be seen in Table 1, 2, 3, and 4.

Table 1. Testing during of the day with indoor conditions.

\begin{tabular}{crrrrr}
\hline \multirow{2}{*}{ Object } & Distance & \multicolumn{2}{c}{ Results } & \multicolumn{3}{c}{$\begin{array}{c}\text { Response } \\
\text { Delay }\end{array}$} \\
\cline { 2 - 7 } & & Left & Right & Left & Right \\
\hline \multirow{3}{*}{$\begin{array}{l}\text { Lipa saqbe } \\
\text { pattern sureq } \\
\text { pangulu }\end{array}$} & $30 \mathrm{~cm}$ & $\mathrm{~V}$ & $\mathrm{~V}$ & $\mathrm{ND}$ & $\mathrm{ND}$ \\
\cline { 2 - 7 } & $60 \mathrm{~cm}$ & $\mathrm{~V}$ & $\mathrm{~V}$ & $\mathrm{ND}$ & $\mathrm{ND}$ \\
\cline { 2 - 7 } & $90 \mathrm{~cm}$ & $\mathrm{X}$ & $\mathrm{X}$ & Fail & Fail \\
\hline \multicolumn{1}{c}{ Sucsess pattern (\%) } & \multicolumn{2}{c}{$50 \%$} & & \multicolumn{2}{c}{$50 \%$}
\end{tabular}

As shown in Table 1 we can see the testing during the day with indoor conditions results. In the system test results during the day with indoor conditions, it can be seen that the success rate reaches $50 \%$ and the rate without delay reaches $50 \%$.

Table 2. Testing of outdoor daytime.

\begin{tabular}{lrrrrr}
\hline \multirow{2}{*}{ Object } & Distance & \multicolumn{2}{c}{ Results } & \multicolumn{3}{c}{$\begin{array}{c}\text { Response } \\
\text { Delay }\end{array}$} \\
\cline { 2 - 7 } & & Left & Right & Left & Right \\
\hline \multirow{3}{*}{$\begin{array}{l}\text { Lipa saqbe } \\
\text { pattern sureq } \\
\text { Pangulu }\end{array}$} & $30 \mathrm{~cm}$ & $\mathrm{~V}$ & $\mathrm{~V}$ & $\mathrm{ND}$ & $\mathrm{ND}$ \\
\cline { 2 - 7 } & $60 \mathrm{~cm}$ & $\mathrm{~V}$ & $\mathrm{~V}$ & $\mathrm{ND}$ & $\mathrm{ND}$ \\
\cline { 2 - 7 } & $90 \mathrm{~cm}$ & $\mathrm{~V}$ & $\mathrm{~V}$ & $\mathrm{ND}$ & $\mathrm{ND}$ \\
\hline \multicolumn{1}{c}{ Succsess pattern (\%) } & \multicolumn{2}{c}{$75 \%$} & & \multicolumn{2}{c}{$75 \%$} \\
\hline
\end{tabular}

As shown in Table 2 we can see the testing of outdoor daytime results. In the system test results during the day with outdoor conditions, it can be seen that the success rate reaches $75 \%$ and the rate without delay reaches $75 \%$.
Table 3. Testing of night indoors.

\begin{tabular}{lrrrrr}
\hline \multirow{2}{*}{ Object } & Distances & \multicolumn{2}{c}{ Reslts } & \multicolumn{2}{c}{$\begin{array}{c}\text { Response } \\
\text { Delay }\end{array}$} \\
\cline { 2 - 6 } & & Left & Right & Left & Right \\
\hline $\begin{array}{l}\text { Lipa saqbe } \\
\text { pattern } \\
\text { sureq } \\
\text { pangulu }\end{array}$ & $30 \mathrm{~cm}$ & $\mathrm{~V}$ & $\mathrm{~V}$ & $\mathrm{ND}$ & $\mathrm{ND}$ \\
\cline { 2 - 6 } & $60 \mathrm{~cm}$ & $\mathrm{X}$ & $\mathrm{V}$ & Fail & $\mathrm{ND}$ \\
\cline { 2 - 6 } & $90 \mathrm{~cm}$ & $\mathrm{X}$ & $\mathrm{X}$ & Gagal & $\mathrm{Fa}$ \\
\hline \multicolumn{1}{c}{ Succsess pattern $(\%)$} & \multicolumn{2}{c}{$37,5 \%$} & \multicolumn{2}{c}{$37,5 \%$} \\
\hline
\end{tabular}

As shown in Table 3 we can see the testing at night indoors results. In the system test results at night with indoor conditions, it can be seen that the success rate reaches $37.5 \%$ and the rate without delay reaches $37.5 \%$ spread of disease trend data.

Table 4. Testing of night outdoors.

\begin{tabular}{|c|c|c|c|c|c|}
\hline \multirow{2}{*}{ Object } & \multirow{2}{*}{ Distance } & \multicolumn{2}{|c|}{ Results } & \multicolumn{2}{|c|}{ Response delay } \\
\hline & & Left & Right & Left & Right \\
\hline \multirow{4}{*}{$\begin{array}{l}\text { Lipa saqbe } \\
\text { pattern sureq } \\
\text { pangulu }\end{array}$} & $30 \mathrm{~cm}$ & $\mathrm{X}$ & $\mathrm{X}$ & Fail & Fail \\
\hline & $60 \mathrm{~cm}$ & $\mathrm{X}$ & $\mathrm{X}$ & Fail & Fail \\
\hline & $90 \mathrm{~cm}$ & $\mathrm{X}$ & $\mathrm{X}$ & Fail & Fail \\
\hline & $120 \mathrm{~cm}$ & $\mathrm{X}$ & $\mathrm{X}$ & Fail & Fail \\
\hline \multicolumn{2}{|c|}{ Succsess pattern (\%) } & \multicolumn{2}{|c|}{$1 \%$} & \multicolumn{2}{|c|}{$1 \%$} \\
\hline
\end{tabular}

As shown in Table 4 we can see the system test results of night with outdoor conditions, it can be seen that the success rate reaches $1 \%$ and the rate without delay reaches $1 \%$.

From the results of the design and application testing carried out, it can be concluded that the image processing application to identify the lipasaqbe pattern has been successfully implemented. From the results of the tests carried out, it is proven that the system is able to work to detect objects and send the results. Whether or not the results of the object image taken have an effect on the light conditions at the time of testing.

\section{CONLUSION}

Based on the results of the completion of this Final Project, suggestions for the development of the next Final Project will be obtained. Here are some suggestions for this final project:

1) The development of this final project is very necessary;

2) In this image processing application, it only identifies the lipa saqbe pattern, for further development, other patterns / motifs can be added;

3) This image processing application can also be developed not only for pattern identification but also for identifying the authenticity of the fabric.

Therefore, we hope that the author's suggestions can be used as a useful contribution, especially in the context 
of Al-Asyariah Mandar University at the Faculty of Computer Science, especially for writers and students who develop it in general.

\section{REFERENCES}

Adyla, N. S., Sulili, A., \& Aswad, M. (2018). Poverty Condition of Lipa' Saqbe Mandar Weavers: Initial Findings from Agriculture Area of West Sulawesi, Indonesia. International Journal of Agriculture System Nationally Accredited Journal Decree, 6(48a),

68-73. https://doi.org/10.20956/ijas.v6i1.1492

Amalia, I., \& Amin, Y. M. (2018). Ekstraksi Fitur Citra Songket Berdasarkan Tekstur Menggunakan Metode Gray Level Co-occurrence Matrix ( GLCM ). 3(2), 64-68.

Bahri, R. S., \& Maliki, I. (2012). Perbandingan Algoritma Template Matching Dan Feature Extraction Pada Optical Character Recognition. Jurnal Komputer Dan Informatika (KOMPUTA), 1(1), 29-35. http://repo.pens.ac.id/1324/1/Paper_TA_MBAH.pd $\mathrm{f}$

Fuad, M. N., \& Suciati, N. (2018). Klasifikasi Multilabel Motif Citra Batik Menggunakan Boosted Random Ferns. JUTI: Jurnal Ilmiah Teknologi Informasi, $16(1)$, https://doi.org/10.12962/j24068535.v16i1.a673

Sulistyo A.S., P. (2016). Sistem Pengenalan Pola Motif Batik Pada Perangkat Android Dengan Jaringan Syaraf Tiruan, Tugas Akhir, Universitas Gadjah Mada, Yogjakarta.

Haerulah, E., \& Ismiyatih, S. (2017). Aplikasi ecommerce penjualan souvenir pernikahan pada toko “ XYZ .” Jurnal Prosisko, 4(1), 43-47. https://ejurnal.lppmunsera.org/index.php/PROSISKO/articl e/download/146/208

Kadir, A., \& Susanto, A. (2013). Teori dan Aplikasi Pengolahan Citra. Yogyakarta: Andi.

Kurniawardhani, A., Suciati, N., \& Arieshanti, I. (2014). Klasifikasi Citra Batik Menggunakan Metode Ekstraksi Ciri yang Invariant Terhadap Rotasi. JUTI: Jurnal Ilmiah Teknologi Informasi, 12(2), 48.

Rangkuti, A. H. (2014). Klasifikasi Motif Batik Berbasis Kemiripan Ciri dengan Wavelet Transform dan Fuzzy Neural Network. ComTech: Computer, Mathematics and Engineering Applications, 5(1), 361. https://doi.org/10.21512/comtech.v5i1.2630

Riesmala, C. P., Rizal, A., \& Novamizanti, L. (2012). budaya Indonesia. Batik telah ditetapkan oleh UNESCO sebagai Warisan Kemanusiaan untuk Budaya Lisan dan Nonbendawi ( Masterpieces of the Oral and Intangible Heritage of menggunakan ekstraksi ciri Rotated Wavelet Transform . Selanjutnya, hasil ekstraksi . 0-6.

Ihwan (2018). "Proses Tenun Lipa Sabbe Mandar". http://pauddikmassulbar.kemdikbud.go. id/. Diakses tanggal 26 Desember 2019

SAA Bowo, A Hidayatno, R. I. (2011). Analisis deteksi tepi untuk mengidentifikasi pola daun. Undergraduate Thesis, Diponegoro University, 1-7.

N. H. Maulida, B. Hidayat, and S. Sa'idah (2019), "Recognition Sasirangan Fabric Base On Texture
With Gabor Filter, Template Matching And Decision Tree Classification," in e-Proceeding of Engineering, pp. 927-934.

B. M. Musthofa, “Aplikasi Betawi Akses: Model Strategi Pelestarian Budaya Betawi Di Era Teknologi Informasi Dan Komunikasi Masa Kini,” J. Sos. Hum. Terap., vol. 2, no. 2, pp. 146-52, 2020.

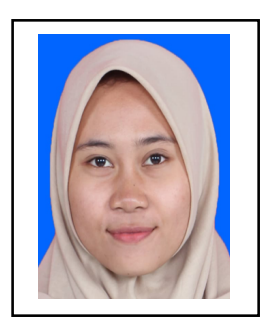

Gustia Ochtavia is undergraduate student at the Faculty of Computer Science in the field of Information Systems, Al Asyariah Mandar University.

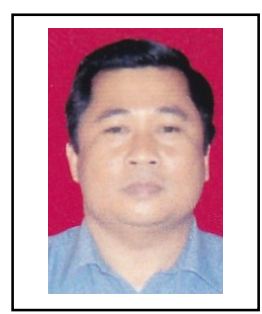

Muhammad Sarjan obtained an M.Si degree at Hasanuddin University Makassar in the Master of Science Study Program, Focused on research in the field of Knowledge Management System and Enterprise Resources Planning, currently pursuing a doctoral program at the Makassar State Islamic University.

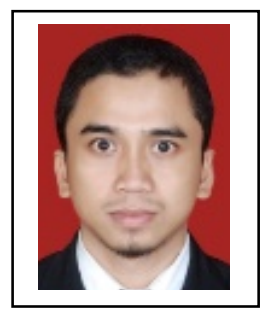

Akhmad Qashlim obtained an M.Kom (Master in Computer) degree at the Information Systems Masters Study Program, Diponegoro University, Semarang, Research focus on image processing and information systems.. 